\title{
PENINGKATAN PRODUKTIVITAS KELOMPOK SANTRI DALAM BUDIDAYA JAMUR TIRAM PUTIH DI PONDOK PESANTREN DARUL HUDA, JABON, SIDOARJO
}

\author{
IMPROVING SANTRI GROUP PRODUCTIVITY IN WHITE PIRAM MUSHROOMS \\ IN PONDOK PESANTREN DARUL HUDA, JABON, SIDOARJO
}

\author{
Nima'tuzahroh \\ Fakultas Sains dan Teknologi \\ Fatimah \\ Fakultas Sains dan Teknologi \\ Nur Indradewi Oktavitri \\ Fakultas Sains dan Teknologi
}

\begin{abstract}
ABSTRAK
Pondok pesantren umumnya memiliki sumber daya manusia dan sumber daya alam, dan memiliki pengaruh besar terhadap masyarakat di sekitar mereka. Sumber daya tersebut dapat dioptimalkan untuk peningkatan produktivitas santri dengan budidaya Jamur Tiram Putih (JTP). Pengabdian masyarakat ini bertujuan untuk penerapan budidaya JTP untuk peningkatan produktivitas santri. Metode yang dilakukan adalah peningkatan wawasan budidaya JTP, pembentukan kader budidaya JTP untuk pembuatan kumbung, berbudidaya JTP, pemanenan dan penjualan JTP. Hasil JTP menunjukkan wawasan santri meningkat rata-rata sebesar $73 \%$ melalui nilai pretest dan post test saat sosialisasi. 3 Kader dibentuk dari koordinasi dengan ketua pondok. Lokasi yang dipilih untuk budidaya jamur berdasarkan kriteria untuk budidaya JTP. Kader budidaya JTP telah mampu membuat kumbung jamur dengan ukuran $4 \times 6 \mathrm{~m}$ di sekitar pondok. Budidaya dilakukan dengan menggunakan 2000 bag log jamur selama 1 bulan. Peningkatan penghasilan bersih dari santri melalui panen jamur dari semula Rp. 0 menjadi Rp. 4.000 .000 tiap 2000 baglog setelah panen. Peningkatan penghasilan ini dapat menunjukkan peningkatan produktivitas santri untuk pemasukan bagi pondok pesantren.
\end{abstract}

Kata kunci: Baglog jamur, kader budidaya jamur, penghasilan budidaya, sosialisasi

\begin{abstract}
Islamic boarding schools generally have human and natural resources, and have a large influence on the communities around them. These resources can be optimized to increase students' productivity with White Oyster Mushroom (JTP) cultivation. This community service aims to implement JTP cultivation to increase students' productivity. The method that was carried out was to increase the knowledge of JTP cultivation, the formation of JTP cultivation cadres for making kumbung, JTP cultivation, JTP harvesting and sales. The JTP results show that the students' insight increased by an average of $73 \%$ through the pretest and posttest scores during socialization. 3 Cadres are formed from coordination with the head of the cottage. The location chosen for mushroom cultivation is based on the criteria for JTP cultivation. JTP cultivation cadres have been able to make $4 \times 6$ m mushroom kumbung around the hut. Cultivation is done using 2000 baglog mushrooms for 1 month. Increased net income from santri through harvesting mushrooms from Rp. 0 to Rp. 4,000,000 every 2000 baglog after harvest. This increase in income can show an increase in santri productivity for income for Islamic boarding schools.
\end{abstract}

Keywords: mushroom baglog, mushroom cultivation cadre, cultivation income, socialization 


\section{PENDAHULUAN}

\section{Latar Belakang}

Pondok pesantren merupakan salah satu lembaga mandiri dan lembaga pendidikan Islam yang mengakar di masyarakat. Pondok pesantren umumnya memiliki sumber daya manusia dan sumber daya alam, dan memiliki pengaruh besar terhadap masyarakat di sekitar mereka. Namun demikian, sumber daya milik pesantren tersebut hingga saat ini umumnya masih belum dimanfaatkan secara maksimal karena pengelolaan yang masih tradisional. Sumber daya manusia dan ketersediaan lahan di lokasi menjadi salah satu sumber daya penting bagi pesantren.

Pondok Pesantren Darul Huda merupakan salah satu pondok pesantren yang memiliki dua potensi tersebut. Pondok pesantren ini terletak di Desa Jemirahan, Kecamatan Jabon, Kabupaten Sidoarjo. Karena terletak di pedesaan, sehingga potensi sumber daya alam masih melimpah, ditunjukkan dengan beberapa bidang tanah yang belum termanfaatkan dengan baik. Dari segi sumber daya manusia, pondok pesantren tersebut memiliki total santri sebesar 485 orang, tersusun atas 245 santri Taman Pendidikan Al-Qur'an dan 240 santri Madrasah Diniyyah.

Hal ini berpotensi dikembangkan kegiatan pengembangan agribisnis, yaitu budidaya jamur tiram. Kegiatan agribisnis dipilih karena kegiatan ini sangat familiar dilakukan oleh masyarakat di sana, dimana mayoritas berprofesi sebagai petani. Sedangkan budidaya jamur tiram berpeluang menjadi komoditas baru di daerah tersebut. Keadaan wilayah juga cukup mendukung untuk budidaya jamur tiram, karena relatif lembab dan masih banyak vegetasi tumbuhan di lahan milik pondok pesantren dan sekelilingnya.

\section{Rumusan Masalah}

Hasil diskusi yang intens dengan mitra pengabdian, maka permasalahan yang di hadapi oleh mitra saat ini adalah:

a. Rendahnya pengetahuan dan wawasan mitra dalam melihat peluang untuk memanfaatkan sumber daya alam sekitar dalam usaha meningkatkan pendapatan.

b. Pengetahuan dan keterampilan dalam budidaya jamur tiram masih kurang.

c Tidak ada fasilitas pendukung dalam budidaya jamur tiram.

\section{Tinjauan Pustaka}

Jamur tiram atau dalam bahasa latin disebut Pleurotus $s p$. merupakan salah satu jamur konsumsi yang bernilai tinggi. Beberapa jenis jamur tiram yang biasa dibudidayakan oleh masyarakat Indonesia, yaitu P.ostreatus (jamur tiram putih), P.flabellatus (jamur tiram merah muda), P. sajor caju (jamur tiram abu- abu), dan P.cystidiosus (jamur tiram abalone). Pada dasarnya semua jenis jamur ini memiliki karakteristik yang hampir sama terutama dari segi morfologi, tetapi secara kasar, warna tubuh buah dapat dibedakan antara jenis yang satu dengan yang lain terutama dalam keadaan segar (Susilawati dan Raharjo, 2010). Jamur tiram adalah organisme heterotrof yang tidak memiliki klorofil (zat hijau daun). Sehingga jamur tiram tidak mampu memproduksi makanannya sendiri. Untuk bertahan hidup, jamur tiram sangat bergantung pada ketersediaan bahan organik di sekitarnya. Nutrisi utama yang dibutuhkan adalah karbon. Sumber karbon dapat berupa serbuk kayu gergajian dan berbagai limbah organik lain. Jamur tiram hidup sebagai organisme saprofit yang tumbuh di kayu-kayu lunak dan memperoleh bahan makanan dengan memanfaatkan sisa-sisa bahan organik Kegiatan budidaya jamur tiram mudah diaplikasikan karena beberapa aspek, diantaranya adalah (Gunawan, 2001):

a. Aspek Pemanfaatan lahan

Budidaya jamur tiram tidak memerlukan tempat atau lahan pertanian yang luas, jadi budidaya jamur bisa dilakukan di lahan yang sempit. Budidaya jamur ini juga umumnya menggunakan rak bertingkat, sehingga sangat efisien dalam penggunaan lahan.

b. Aspek Teknologi

Budidaya jamur tiram sangat mudah untuk dilakukan dan tidak membutuhkan suatu teknologi yang mutakhir, sehingga cukup mudah dilakukan oleh masyarakat awam yang sebelumnya tidak memiliki pengalaman di bidang agribisnis. Jamur tiram sangat mudah dibudidayakan, karena proses perlakuan dalam budidaya jamur tiram sangat berbeda dengan cara perlakuan pada budidaya tanaman lainnya. Dalam budidaya jamur tiram petani hanya perlu mengontrol kelembapan suhu tempat budidaya menjaga kebersihan lingkungan tempat budidaya dan menyiram setiap hari. Selain itu, tidak diperlukan alatalat bertani pada umumnya yaitu, cangkul, garpu tanah dan lainnya.

c. Aspek Ekonomi

Budidaya jamur tiram dapat dilakukan oleh setiap orang dengan modal yang sedikit. Hasil dari budidaya dapat dikonsumsi sendiri sebagai pemenuhan gizi dan hasil lebihnya dapat dijual sebagai tambahan pendapatan, sehingga masyarakat tersebut akan lebih sejahtera. Jamur tiram sangat toleran terhadap perubahan cuaca dan musim, sehingga budidaya jamur lebih produktif dibanding tanaman pertanian lainnya, tidak mengenal waktu dan musim untuk dapat tumbuh dan dipanen.

d. Aspek Sosial

Komoditas hasil budidaya jamur tiram dapat diterima oleh masyarakat luas dan dapat diterima oleh berbagai lapisan masyarakat, berbagai adat, berbagai suku, dan agama. Sehingga dengan kata lain bahwa budidaya jamur tiram tidak bertentangan dengan suku, agama, ras dan adat istiadat yang ada di masyarakat Indonesia.

Kelebihan-kelebihan budidaya jamur tiram di atas, terutama dalam hal perlakuan budidaya, dapat disimpulkan 
bahwa budidaya jamur tiram tidak menyita banyak waktu, sehingga budidaya jamur tiram dapat dijalankan sebagai usaha sampingan bagi mereka yang memiliki rutinitas kesibukan di lingkungan mitra.

Berdasarkan uraian analisis situasi tersebut, pondok pesantren tersebut berpotensi dikembangkan kegiatan pengembangan agribisnis, yaitu budidaya jamur tiram.

\section{Tujuan dan Manfaat}

Tujuan dari program pengabdian:

a. Peningkatan pengetahuan dan wawasan mitra dalam melihat peluang untuk memanfaatkan sumber daya alam sekitar dalam usaha meningkatkan pendapatan.

b. Peningkatan pengetahuan dan keterampilan dalam budidaya jamur tiram masih kurang.

c. Tersedia fasilitas pendukung dalam budidaya jamur tiram seperti pembuatan kumbung, baglog, serta cara pemanenan.

Manfaat bagi para santri, selain mendapatkan ilmu yang berharga mengenai usaha agribisnis untuk bekal masa depannya juga mendapatkan tambahan finansial untuk biaya pendidikan dan kebutuhan primer lainnya. Hal ini penting untuk menumbuhkan sikap mandiri, terutama mandiri secara ekonomi, dalam masyarakat santri, karena berdasarkan survey pada umumnya santri di pondok pesantren tersebut merupakan golongan menengah ke bawah. Pada tingkat yang lebih jauh, kegiatan pemberdayaan ini tidak hanya berdampak pada santri, tetapi ke lingkup pesantren secara luas dan menularkannya kepada masyarakat sekitar pesantren.

\section{METODE PENGABDIAN}

Metode pengabdian kepada masyarakat dilakukan dengan beberapa tahapan yang dijelaskan pada sub bab 1 hingga 3 .

\section{Waktu dan Tempat Pengabdian}

Waktu pelaksanaan Program Pengabdian Masyarakat dilaksanakan pada bulan Maret-September 2017.

\section{Metode dan Rancangan Pengabdian}

Pelaksanaan kegiatan IbM ini dilakukan dengan beberapa langkah, yaitu: perencanaan, tindakan, observasi dan evaluasi. Kegiatan-kegiatan atau aktivitas-aktivitas dari masing-masing tahapan adalah sebagai berikut.

a. Perencanaan

Kegiatan-kegiatan yang dilakukan pada tahap perencanaan adalah:

1. Survei kondisi pesantren dan lokasi yang tepat untuk pembangunan kumbung jamur tiram.
2. Sosialisasi program Pengabdian kepada Masyarakat kepada pengurus pondok pesantren untuk pemaparan program pelatihan.

3. Pembentukan dua kelompok santri, yaitu santri diniyah ula dan santri diniyah wustho untuk budidaya jamur tiram.

4. Penyusunan modul budidaya jamur tiram untuk santri pondok pesantren Darul Huda.

b. Tindakan

Tindakan dalam kegiatan ini berupa implementasi program pelatihan. Kegiatan-kegiatan yang dilakukan dalam implementasi program adalah:

1. Peningkatan pengetahuan budidaya jamur tiram kepada kelompok santri. Metode yang ditawarkan adalah ceramah, tanya jawab, diskusi. Pretest dan post test dilakukan untuk mengukur pemahaman mitra terhadap materi yang diberikan.

2. Pembangunan kumbung untuk budidaya jamur tiram. Pelaksanaan pelatihan dilakukan baik secara teori maupun praktek dengan narasumber ahli, yaitu dari tim pengabdian kepada masyarakat. Materi yang diberikan adalah pelatihan teori dan praktek pembuatan kumbung. Metode pelatihan yang digunakan adalah ceramah, tanya jawab, diskusi dan latihan selama dua kali kunjungan mitra.

3. Pembinaan dan pelatihan dimulai dari persiapan dan pengondisian kumbung sebelum baglog dimasukkan, cara perawatan baglog jamur, dan cara pemanenan. Pembinaan manajemen bisnis dan pemasaran juga dilakukan bersamaan dengan pelatihan budidaya. Metode pelatihan yang digunakan adalah ceramah, tanya jawab, diskusi dan latihan selama enam kali kunjungan mitra. Untuk mendukung keberhasilan pelatihan dan produksi diberikan bantuan 2000 unit baglog.

c. Observasi dan Evaluasi

Observasi dilakukan selama masa kegiatan. Observasi berkala dilakukan tiap bulan dan observasi insidental jika diperlukan oleh pihak pondok pesantren di luar observasi berkala. Instrumen yang digunakan berupa catatan lapangan. Beberapa hal yang diobservasi adalah kendala-kendala, kekurangan, dan kelemahan-kelemahan yang muncul dalam proses budidaya jamur tiram. Evaluasi dilakukan terhadap proses pembudidayaan dan hasil budidaya, berupa kuantitas dan kualitas produk jamur tiram yang dihasilkan. Evaluasi ini dilakukan dalam rangka untuk menetapkan rekomendasi terhadap keberlangsungan atau pengembangan kegiatan-kegiatan berikutnya. 


\section{Peserta Sosialisasi dan Kader}

Peserta untuk sosialisasi berasal dari undangan kepada para santri sejumlah 30 orang. Berdasarkan hasil sosialisasi dipilih 3 kader yang akan bertanggung jawab dalam pengelolaan budidaya jamur, mulai dari pembangunan kumbung, pengadaan baglog, perawatan baglog, dan pemanenan jamur tiram.

\section{HASIL DAN PEMBAHASAN}

Pengabdian ini dilakukan dengan terlebih dahulu mengadakan diskusi antara tim pengabdian dengan kelompok mitra pengabdian. Tujuan dari dilaksanakannya diskusi ini adalah untuk mencari dan merumuskan permasalahan sebenarnya yang dialami oleh kelompok mitra pengabdian. Tindak lanjut dari diskusi adalah memotivasi mitra dalam pemberdayaan komunitasnya agar mampu lebih produktif, meningkatkan pengetahuan mitra mengenai masalah manajemen usaha, perhitungan harga pokok produksi dan pelatihan peningkatan keterampilan budidaya jamur.

Terdapat 3 lokasi yang berpotensi untuk kegiatan ini (Gambar 1.a-c). Berdasarkan hasil diskusi dengan pihak pondok pesantren diputuskan untuk menggunakan lahan pada Gambar 1.a. Pemilihan lahan ini mengakomodasi dari sisi aksesibilitas, keamanan, jenis tanah, dan faktor-faktor pendukung lain, misalnya naungan pohon dan sirkulasi udara. Jenis tanah di antara tiga lahan tersebut tidak berbeda jauh,
Tabel 1. Skoring penilaian alternatif lahan untuk kegiatan.

\begin{tabular}{lccc}
\hline \multicolumn{1}{c}{ Parameter } & Lahan A & Lahan B & Lahan C \\
\hline Aksesibilitas & ++ & ++ & + \\
Keamanan & ++ & + & +++ \\
Faktor pendukung & ++ & + & +++ \\
Naungan pohon & + & + & ++ \\
Sirkulasi udara & ++ & ++ & ++ \\
\hline
\end{tabular}

tetapi lahan yang dipilih dalam kegiatan ini memiliki nilai lebih pada aspek aksesibilitas dan keamanan (Tabel 1).

Pembinaan untuk membangun rumah jamur dilakukan dengan pemberian materi teori tentang persyaratan atau kualifikasi rumah jamur pada para santri. Dari segi sumber daya manusia, pondok pesantren tersebut memiliki total santri sebesar 485 orang, tersusun atas 245 santri Taman Pendidikan Al-Qur'an dan 240 santri Madrasah Diniyyah.

Pemberian materi dilakukan baik secara klasikal dalam bentuk ceramah maupun materi teknis yang dilakukan di lahan yang akan digunakan. Kegiatan ini bertujuan untuk memberikan gambaran tata acara pembangunan rumah jamur yang disesuaikan dengan keadaan lahan mitra. Hasil pemberian materi di evaluasi dalam bentuk pretest dan post test (Gambar 2). Evaluasi pretest dan post test menunjukkan bahwa terdapat peningkatan wawasan dan pengetahuan mitra terkait jamur dan budidayanya.
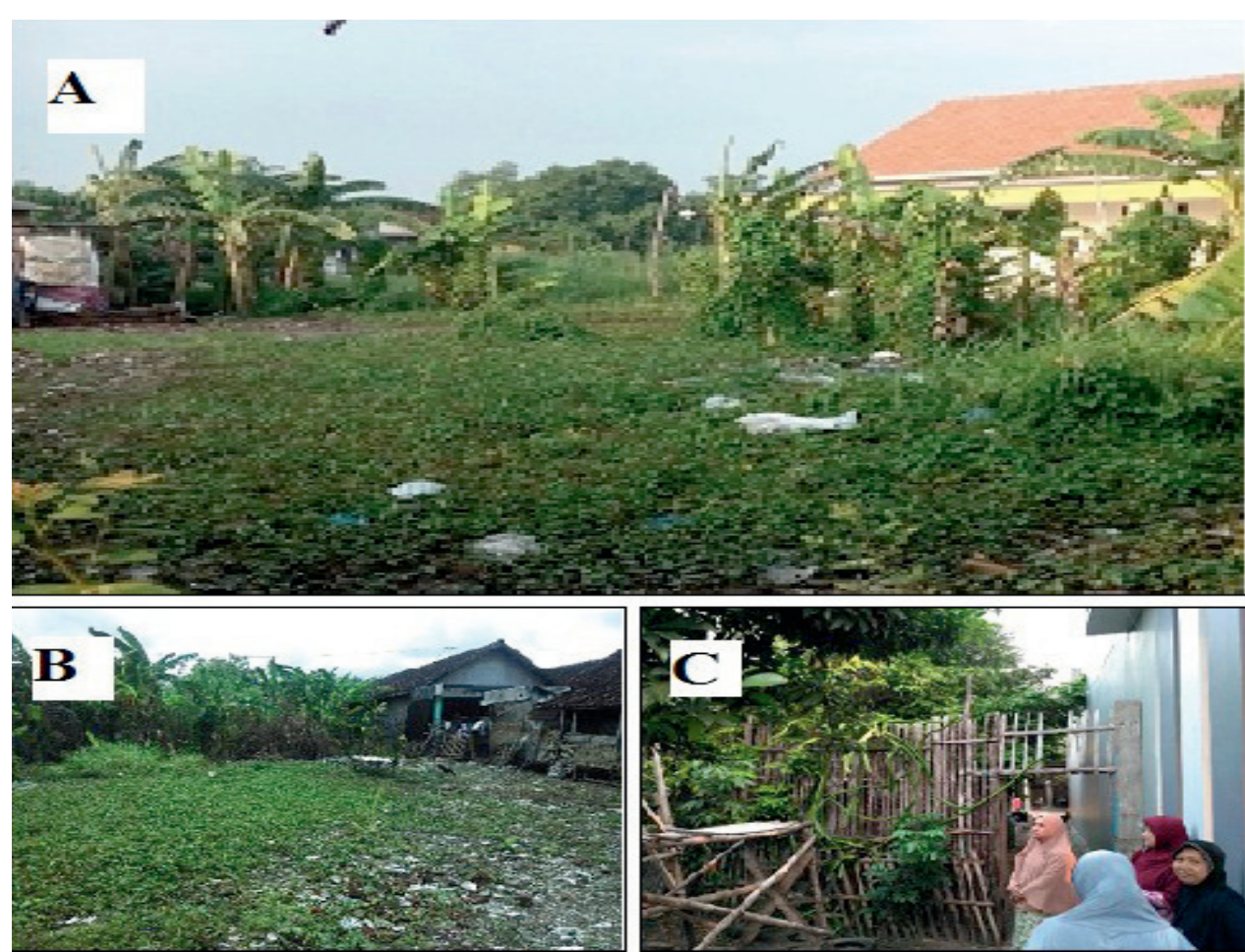

Gambar 1. Tiga lahan alternatif yang digunakan untuk kegiatan budidaya jamur tiram. 


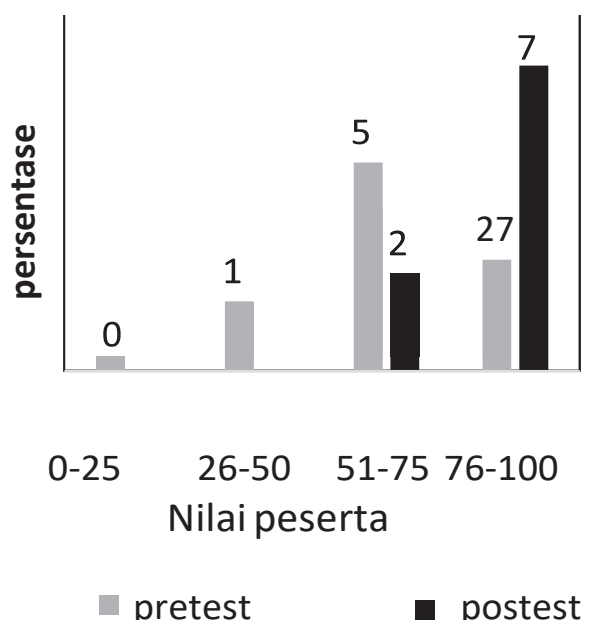

Gambar 2. Hasil pretest dan post test peserta pelatihan budidaya jamur tiram

Peserta dengan nilai pretest dan post test terbaik dipilih menjadi kader yang kemudian bertugas mengoordinir kegiatan budidaya kepada rekan-rekannya. Tiga kader yang terpilih diberikan pelatihan intensif mengenai cara pembuatan rumah jamur "kumbung" dan media tanam jamur "baglog".

Pelatihan menitikberatkan pada luasan area yang tersedia sehingga dapat menampung baglog dengan jumlah 2000. Pelatihan ini berfungsi untuk mempermudah penanganan budidaya seperti penyusunan media tanam, akses panen dan pemeliharaan serta segi estetika. Selanjutnya kader akan menyampaikan informasi dan mengatur kinerja sesuai dengan pelatihan.

Mitra selanjutnya membangun sendiri rumah jamur dengan pendampingan tim pengabdian kepada masyarakat, yang sekaligus untuk mengevaluasi materi dan praktik tentang pembangunan rumah jamur benar-benar dipahami oleh mitra. Hasil evaluasi kegiatan pembangunan rumah jamur

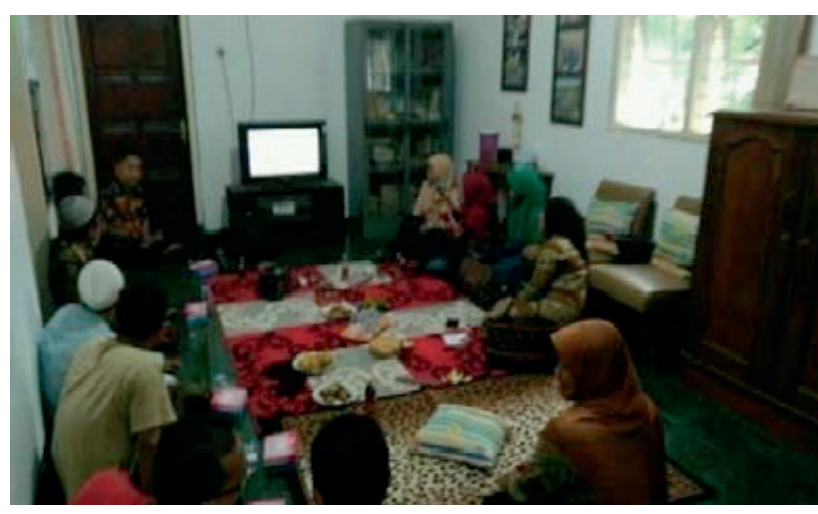

Gambar 3. Pelatihan para kader terkait Pembangunan dan budidaya jamur

Mitra selanjutnya membangun sendiri rumah jamur dengan pendampingan tim pengabdian kepada masyarakat, yang sekaligus untuk mengevaluasi materi dan praktik tentang pembangunan rumah jamur benar-benar dipahami oleh mitra. Hasil evaluasi kegiatan pembangunan rumah jamur menunjukkan bahwa mitra telah mampu membangun sendiri rumah jamur dengan baik (Gambar 3). Rumah jamur yang didesain memiliki dimensi panjang 6 meter, lebar 4 meter, dan tinggi 3 meter, serta memiliki kapasitas sekitar 2000 baglog jamur.

Pengondisian rumah jamur dilakukan untuk persiapan budidaya jamur tiram. Dikarenakan jamur membutuhkan kelembapan yang relatif tinggi, dilakukan penyiraman setiap hari pada lantai rumah jamur. Selain itu, dinding rumah jamur didesain menggunakan bambu untuk memberi ventilasi udara dan ditutup sebagian dengan plastik tebal pada bagian dalam untuk mencegah terjadinya penguapan berlebih. Setelah satu minggu dilakukan Pengondisian, baglog jamur diletakkan pada rak-rak kayu yang didesain bertingkat untuk menghemat tempat.
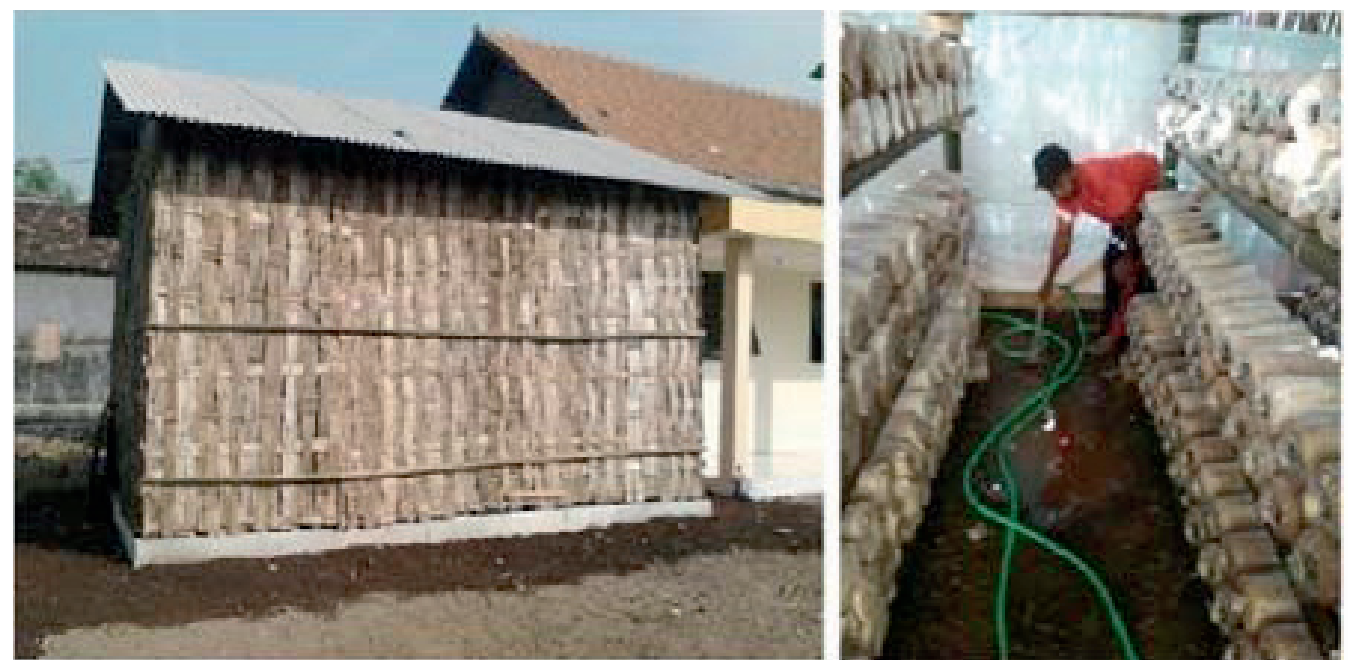

Gambar 4. Hasil pembangunan rumah jamur untuk budidaya jamur tiram di Pondok Pesantren Darul Huda. 
Tabel 2. Perhitungan penghasilan budidaya jamur

\begin{tabular}{lcc}
\hline \multicolumn{1}{c}{ Keterangan } & $\begin{array}{r}\text { Sebelum } \\
\text { Budidaya }\end{array}$ & $\begin{array}{c}\text { Sesudah } \\
\text { Budidaya }\end{array}$ \\
\hline Jumlah Baglog & 0 & 2.000 \\
Jumlah panen jamur (kg) & 0 & 500 \\
Harga bersih jamur per kg (Rp) & 8.000 & 8.000 \\
$\begin{array}{l}\text { Penghasilan budidaya jamur } \\
\text { tiap 500 kg panen jamur (Rp) }\end{array}$ & 0 & 4.000 .000 \\
\hline
\end{tabular}

Peletakan baglog pada rumah jamur tidak dilakukan serentak, untuk menghindari terjadinya panen raya yang terjadi akibat waktu produksi yang bersamaan. Setelah dilakukan peletakan baglog, perawatan dan monitoring dilakukan setiap hari oleh mitra, meliputi penyiraman setiap hari untuk menjaga kelembapan dan monitoring hama yang berpotensi merusak produksi jamur tiram.

Pelatihan selanjutnya meliputi cara pemanenan dan pengemasan produk. Prinsip dasar penanganan pasca panen adalah melaksanakan dengan hati-hati agar tidak terjadi kerusakan, menghambat proses pembusukan akibat kerusakan produk, menghambat laju penurunan laju kesegaran. Tujuan pelatihan ini adalah untuk meningkatkan kualitas produk setelah pemanenan. Pelatihan juga dilakukan untuk pengolahan jamur menjadi produk siap saji sehingga hasil budidaya dapat dijual dalam keadaan segar maupun setelah diolah. Penyakit pada jamur dapat menurunkan penghasilan budidaya jamur. Infeksi badan buah jamur tiram dan menyebabkan penurunan hasil panen hingga 50-70\% (Verma and Sharma., 1999). Berdasarkan hasil pelatihan, para kader untuk budidaya jamur juga disampaikan cara perhitungan penghasilan sebelum dan sesudah budidaya seperti pada Tabel 2.

\section{SIMPULAN, SARAN, DAN REKOMENDASI}

Simpulan dari program pengabdian masyarakat ini adalah proses sosialisasi mampu meningkatkan wawasan santri.
$73 \%$ santri paham dengan budidaya jamur. Penunjukan kader pengelola budidaya jamur serta pelatihan budidaya dari pembuatan kumbung hingga pemanenan menjadi faktor penting dalam budidaya jamur. Program pengabdian masyarakat ini juga tersedianya fasilitas kumbung jamur, beserta rak dan baglog jamur. Pengabdian masyarakat ini juga menyediakan fasilitas timbangan untuk jamur, alat penyiram jamur agar para santri menjadi mandiri untuk proses budidaya jamurnya. Budidaya jamur ini juga memberi tambahan penghasilan sebesar Rp. 4.000.000,- tiap 500 kg panen jamur.

Saran nya agar program pendampingan masyarakat ini dapat dilanjutkan untuk pemasaran jamur ke luar wilayah lokasi Pengabdian Masyarakat. Pondok pesantren sejenis di lain tepat juga dapat direkomendasikan memungkinkan untuk pelaksanaan program pengabdian masyarakat sejenis.

\section{UCAPAN TERIMA KASIH}

Kegiatan ini dibiayai oleh Direktorat Riset dan Pengabdian Masyarakat, Direktorat Jenderal Penguatan Riset dan Pengembangan, Kementerian Riset, Teknologi, dan Pendidikan Tinggi dengan Surat Perjanjian Pendanaan Program Pengabdian Masyarakat Tahun Anggaran 2017 Nomor: 004/SP2H/PPM/DRPM/V/2017. Terima kasih diucapkan kepada pengurus Pondok Pesantren Darul Huda, Desa Jemirahan, Kecamatan Jabon, Sidoarjo atas kerja samanya dalam pelaksanaan kegiatan ini.

\section{DAFTAR PUSTAKA}

Gunawan W.A. (2008). Usaha Pembibitan Jamur. Jakarta: Penebar Swadaya

Susilawati dan Raharjo B. 2010. Budidaya Jamur Tiram (Pleourotus ostreatus var florida) yang Ramah Lingkungan. Sumatera Barat: BPTP Sumatera Barat.

Verma, L.R and Sharma R.C. 1999. Diseases of Horticultural Crops: Vegetables, Ornamentals, and Mushrooms. New Delhi: Indus Publishing Company. 